\title{
Business Continuity: Application of The Value of Catur Purusa Artha and Product Innovation in Holding Company of BUMDes
}

\author{
Ni Luh De Erik Trisnawati ${ }^{*}$, Riana Dewi Kartika ${ }^{2}$, Ni Luh Sri Kasih ${ }^{3}$
}

1,2,3 Sekolah Tinggi Ilmu Ekonomi Satya Dharma Singaraja, Singaraja, Indonesia

\section{A R T I C L E I N F O}

Article history

Received April 01, 2021

Revised April 03, 2021

Accepted July 01, 2021

Available online August 25, 2021

Keywords:

Catur Purusa Artha Value, Product Innovation, Business Continuity

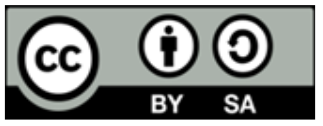

This is an open access article under the CC BY-SA license.

Copyright (C) 2021 by Author. Published by Universitas Pendidikan Ganesha.

\begin{abstract}
A B S T R A C T
Business management based on the local culture of catur purusa artha by making dharma (truth) the basis for carrying out all its activities, creating internal conditions in the form of a conducive work climate. This study aims to examine the application of the value of catur purusa artha and product innovation in creating business continuity. The research population is all active BUMDes in Buleleng Regency. Sampling in this study using random sampling technique in order to obtain as many as 92 observational data. The data analysis technique used in this study was the Component based SEM, Partial Least Square (PLS) analysis method. The results showed that the value of Catur purusa artha had a significant effect on product innovation. Product innovation has a significant effect on business continuity and the value of catur purusa artha affects business continuity through product innovation. This study also found that business management based on the local culture of Catur Purusa Artha by making dharma (truth), as the basis for carrying out all its activities, creates internal conditions in the form of a conducive work climate. BUMDes managers, including all employees who work comfortably based on dharma, have actually come up with creative ideas in product development. Management of business units based on dharma provides awareness to act in the truth and creates an environment that minimizes abuse of authority, including various other forms of wrongdoing. The concept of dharma also emphasizes to always provide good service to customers.
\end{abstract}

\section{INTRODUCTION}

The coronavirus pandemic has brought major disruptions all around the world, there have been restrictions on business operations, business activities have shifted dramatically, and supply chains have been disrupted. The disastrous financial effects of this ongoing crisis are enormous and small businesses are being severely impacted. Whenever a crisis occurs, micro, small and medium enterprises (UMKM) such as Village-Owned Enterprises (BUMDes) tend to be more vulnerable to impact than large companies. In the midst of these challenging conditions, many small businesses directly suffer losses. While some struggle to cope and survive in unprecedented situations. BUMDes was built as a realization of the program to build the country from the periphery by strengthening regions and villages. BUMDes is expected to be an instrument for realizing the eighth sustainable development goal, namely supporting the village economy. However, the current pandemic paralysed the entire economy, causing the number of active BUMDes to continue to decline. The Kemendes PDTT has announced to take action to revitalize BUMDes so that they are able to rise during the pandemic. This is because based on the latest data obtained, before the pandemic, BUMDes turnover reached Rp. 2.79 trillion, while after the pandemic occurred it was only able to reach Rp. 938 billion.

The same thing is being faced by BUMDes in Buleleng Regency, to struggle to be able to rise again. Buleleng Regency is recorded to have 84 active BUMDes, but broadcasts on Kompas TV in 2020, of all BUMDes in Buleleng there are only five BUMDes that are in the best group. While others still show poor performance. The difficulty of customers in meeting their daily needs has an impact on the declining performance of BUMDes. In addition, due to the impact of the Covid-19 pandemic, eight villages that do not yet have BUMDes have cancelled their intention to form BUMDes. Companies must immediately make decisions and take action during a crisis, taking into account the recovery strategy (Ernst \& Young, 2020).

*Corresponding author

E-mail: niluhdeeriktrisna@gmail.com 
When the crisis ends, it will be clear which companies have the resilience and agility to reshape their business strategies to thrive in the future. For companies to be successful during economic downturns, companies need the ability to adapt and improvise when conditions change. Companies must ensure the safety of their workforce, comply with regulations, and take steps to maintain business and ensure business continuity (Miska et al., 2018; Srisathan et al., 2020). COVID-19 has forced companies to reconsider sustainable business strategies to safeguard the company's future, through model changes operations such as flexible working modes, product service model innovations, business procedures and management. Besides, there are many lessons that can be understood by companies after this pandemic crisis has passed, where companies have the opportunity to analyze and design business continuity strategies. This is something that must be done immediately BUMDes in designing recovery strategies. If this condition is not addressed immediately, more and more BUMdes will close. To maintain the continuity of its business, BUMDes must immediately make new adaptations in changing ways of working through strengthening its governance. One of them is by changing the business model through product service innovations that are offered, so that BUMDes can continue to exist and become a holding company in the style of Traditional Villages in the future. BUMDes operating in rural areas in Bali has a unique side, where strong cultural values still apply in village communities (Rahmawati, E 2020). So that the success of BUMDes management should not be separated from the cultural values that exist in the community. A business unit built in the Balinese community; its operational activities will be more developed if it applies the concept of dharma as the basis of its business activities.

The implementation of the dharma concept in the cultural values of Catur Purusa Artha as a new adaptation of BUMDes management will encourage administrators to make more appropriate product service innovation choices so that they can maintain business continuity in the future. The concept of business management based on this dharma has previously been applied to LPDs in Buleleng district and managed to maximize their financial performance (Erik Trisnawati et al., 2019). An externally oriented organizational culture is central to excellence in product development based on customer desires. The large number of product choices accompanied by creativity or innovation in their presentation is certainly a reliable competitive advantage in winning the competition (Widiarta et al., 2020). In addition, (Mosteanu, 2020) also explained that the application of cultural values in the company that involves all employees is one of the keys to managing the business and ensuring business continuity. A study on the impact of the pandemic on micro-enterprises, explored how micro-entrepreneurs experienced the crisis and what decisions they made for business continuity (Fabeil et al., 2020). The results found that there was no systematic management applied in dealing with crisis situations, but they tried to reduce the impact, one of which was through changes in marketing methods. To ensure micro-entrepreneurs manage their business in crisis situations especially in rural areas, it is very important to provide assistance in the form of business management knowledge such as online marketing techniques, new product development, and pricing strategies during crisis. So that the purpose of this study is to find a model for managing BUMDes in maintaining business continuity in the new era, through the implementation of the dharma concept in the Catur Purusa Artha value and product innovation.

The success of implementing business management depends on the cultural values that are believed to be true, which are implemented by BUMDes. The value of Catur purusa artha as a cultural value is believed to be the basis for behavior. The value of Catur Purusa Artha means four human goals in life which consist of Dharma (truth), Artha (material possessions), Kama (enjoyment of life) and Moksa (eternal freedom and happiness). The value of Catur Purusa Artha can be used as a basis for managing businesses operating in rural areas in Bali (Erik Trisnawati et al., 2019). The culture of Catur Purusa Artha provides an understanding of four things that are important for BUMDes in business management. (1) Dharma (truth) (2) Kama (Satisfaction/enjoyment of life), is a BUMDes effort to increase customer satisfaction, develop relationships and build an institutional image (brand image) in a sustainable manner. (3) Artha (assets/materials), is an effort to achieve financial targets through efficient operational activities, and increased sales. (4) Moksa (eternal freedom and happiness), is the ultimate goal of the business, namely increasing the value that is realized through the growth of BUMDes performance, business reputation and sustainable business capabilities.

Innovation is part of a framework that connects aspects of corporate culture with the ability to innovate and improve company performance through consumer buying decisions. The characteristics of innovation consist of 5 things, namely: Relative advantage is the extent to which the innovation appears to be superior to products that already exist, Compatibility is the extent to which product innovations that are carried out are appropriate and suitable. with the value and experience of the customer, Complexity is the extent to which the innovation is difficult to understand, understand or use by consumers, Divisibility (ability to be shared or broken up) which is the extent to which the innovation can be tried on a limited basis, Communicability is the extent to which the results of the use the innovation can be communicated 
to others (Kotler and Keller, 2016). Business continuity is a condition of a business, in which there are ways to maintain, develop and protect resources and meet the needs that exist in a business (Suryaningsih \& Kartika, 2019). Business Continuity is assessed by adapting several important aspects of a business, which include: Capital, Human Resources, Production, and Marketing. Dynamic and fluctuating competitive conditions make business actors sensitive to changes, so business actors must build competitive advantages in order to have an advantage in competition and be sustainable in the market (Dalimunthe, 2017). BUMDes as a business unit must also adapt, especially in the current situation where the performance of BUMDes has decreased due to the impact of the COVID-19 pandemic. Business continuity must be maintained in total business operations in order to remain competitive in the market. Current business continuity strategies are increasingly focusing on how to manage new knowledge of ideas and practices that can expand the business. Innovation plays a key strategic role towards effective business continuity (Lopes et al., 2017).

Innovations, especially those related to products and services, have a strong correlation to the competitive position and increase in the market. Innovation contributes greatly to the company's competitive ability by introducing innovative new products, entering the market faster than competitors and obtaining better and more opportunities in the market, compared to its competitors. The variety of products offered will affect the continuity of a company's business (Suryaningsih \& Kartika, 2019). From a positive point of view, product innovation represents providing solutions to market threats and opportunities, creating the basis for the company's future survival and success. Research conducted by (Anggraini et al., 2020) on UMKM also found that product innovation affects the development of small and medium enterprises. BUMDes operating in rural areas in Bali certainly absorb cultural values that are still strong in village communities. So that the success of BUMDes management should not be separated from the cultural values that exist in the community. A business unit that is built in the Balinese community, will develop its operational activities and achieve maximum performance if it applies the concept of dharma as the foundation of its business activities. The implementation of the dharma concept in the new adaptation of BUMDes management will encourage BUMDes management to make more appropriate product service innovation choices. The research conducted by (Bilan et al., 2020) regarding business continuity where an innovative organizational culture significantly influences the company's continuity. (Di Fabio, 2017) also revealed that a healthy organization with good cultural values will create a conducive environment for the health and safety of employees. A healthy organization will lead to a healthy and successful business in the future. So that companies that have a good culture and are serviceoriented have advantages in product innovation so that they can maintain business continuity in the future and can become a holding company. This study aims to examine the application of the value of catur purusa artha and product innovation in creating business continuity.

\section{METHODS}

This study examines the causal relationship between the values of Catur Purusa Artha, Product Innovation and Business Continuity. The touch of the concept of dharma in this study is the cultural value of Catur Purusa Artha which is the life goal of the Balinese people as a value that is maintained for the management of BUMDes. Which consists of Dharma, Artha, Kama and Moksa which when associated with the Resource Based View (RBV) Theory is an intangible asset. The concept of dharma underlies business activities on the basis of goodness through service to customers (Erik Trisnawati et al., 2019). This BUMDes management model combines a touch of cultural values of catur purusa artha which uses dharma as its basis combined with product innovation will be a strength in maintaining business continuity so that a holding company in the style of a traditional village can be realized. The research was conducted in all BUMDes in Buleleng Regency. The reason is that of the 84 BUMDes operating in nine sub-districts namely, Banjar, Sukasada, Sawan, Kubutambahan, Tejakula, Seririt, Busungbiu, Gerogak, and Buleleng sub-districts in 2020, only five BUMDes were declared the best performers and the rest are still in performance not good. The data in this study were collected by distributing questionnaires to all BUMDES in Buleleng Regency using the Agree-Disagree Scale interval scale with a range of values from 1 to 5 .

The variable value of Catur Purusa Arthain this study was measured using the indicators of the four parts of the value of Catur Purusa Arthaincluding: (1) Dharma (truth), which is the main basis for BUMDes in carrying out their business activities. (2) Kama (Satisfaction/enjoyment of life), is an effort of BUMDes to increase customer satisfaction, develop relationships and build an institutional image (brand image) in a sustainable manner. (3) Artha (assets/materials), is an effort to achieve financial targets through efficient operational activities, and increased sales. (4) Moksa (eternal freedom and happiness), is the ultimate goal of the business, namely increasing the value that is realized through improving the performance of BUMDes, business reputation and sustainable business capabilities. Product innovation variable, in this study is part of a framework that connects aspects of corporate culture with the ability to 
innovate. Which is measured using indicators Relative advantage, Compatibility, Complexity, Divisibility, Communicability (Kotler, Philip and Keller, 2016). While the business continuity variable is a business condition, in which there are ways to maintain, develop and protect resources and meet existing needs. In a business, business continuity is measured using indicators of capital, human resources, production and marketing (Suryaningsih \& Kartika, 2019). The data analysis technique used to test the research hypothesis is Structural Equation Modeling (SEM) with Partial Least Square (PLS) approach. The analytical steps used in the PLS approach include: (a) Outer Model testing for reflexive indicators evaluated with covergent and for indicators forming latent constructs with discriminant validity, as well as through composite reliability and Cronbach alpha for the indicator block, (b) Model Testing Structural (InnerModel) was performed using R-square for the dependent construct, Stone-Geisser Q-square for predictive relevance, and t-test and the significance of the coefficients of structural path parameters (Ghozali, 2015).

\section{RESULTS AND DISCUSSIONS}

\section{Partial Least Square Analysis Results Outer Model Evaluation}

The outer model is a test of the measurement of each latent variable or the measurement of indicators of each variable. A good construct is required if the AVE value is $>0.50$. A construct is said to have high reliability if the composite reliability value is above $>0.70$, cronboach's alpha $>0.60$, and rho_A $>0.70$ (Ghozali \& Latan, 2015). Table 1 presents the values of Cronbachs Alpha, rho_A, Composite Reliability and Average Variance Extracted (AVE) for all variables.

Table 1. Cronbachs Alpha, rho_A, Composite Reliability dan Average Variance Extracted Value Construct Reliability and Validity

\begin{tabular}{lcccc}
\hline & $\begin{array}{c}\text { Cronbach's } \\
\text { Alpha }\end{array}$ & rho_A & $\begin{array}{c}\text { Composite } \\
\text { Reliability }\end{array}$ & $\begin{array}{c}\text { Average Variance } \\
\text { Extracted (AVE) }\end{array}$ \\
\hline Catur Purusa Artha Value & 0.876 & 0.913 & 0.954 & 0.668 \\
Product Innovation & 0.894 & 0.900 & 0.938 & 0.721 \\
Business Continuity & 0.896 & 0.897 & 0.953 & 0.667 \\
\hline
\end{tabular}

\section{Structural Model Testing (Inner Model)}

The Structural Model in PLS was evaluated using R-squares (R) for the dependent construct. Rsquares explain the diversity of endogenous constructs that can be explained by exogenous constructs simultaneously. R-Squares values of $0.75,0.50$, and 0.25 can be concluded that the model is strong, moderate and weak (Ghozali \& Latan, 2015). Table 2 presents about R Square.

Table 2. R-Square Value

\begin{tabular}{cc}
\hline & R Square \\
\hline Product Innovation & 0.765 \\
Business Continuity & 0.889 \\
\hline
\end{tabular}

From table 2, the R-square value is obtained that the Product Innovation variable can be explained by the Catur Purusa Artha value variable of $76.5 \%$ and the Business Continuity variable can be explained by the $88.9 \%$ Catur Purusa Arthavalue variable and product innovation The R-square value is classified as a strong model. The results of hypothesis testing are seen from the values contained in the output results for the inner weight. The following are the results of the test of the relationship between the variables (path) presented in Table 3.

Table 3. Test Results of Relationships between Variables (Path Coefficient)

\begin{tabular}{|c|c|c|c|c|c|}
\hline & $\begin{array}{c}\text { Original } \\
\text { Sample } \\
(0)\end{array}$ & $\begin{array}{c}\text { Sample } \\
\text { Mean } \\
\text { (M) }\end{array}$ & $\begin{array}{l}\text { Standar } \\
\text { Deviation } \\
\text { (STDEV) }\end{array}$ & $\begin{array}{c}\mathbf{T} \\
\text { Statistics }\end{array}$ & $\begin{array}{c}\mathbf{P} \\
\text { Value }\end{array}$ \\
\hline $\begin{array}{llll}\text { Catur Purusa } & \text { Artha } & \text { Value } & \text {->Product } \\
\text { Innovation } & & & \end{array}$ & 0.837 & 0.836 & 0.926 & 7.569 & 0.000 \\
\hline Product Innovation ->Business Continuity & 0.590 & 0.594 & 0.409 & 3.476 & 0.000 \\
\hline $\begin{array}{l}\text { Catur Purusa Artha Value ->Business } \\
\text { Continuity }\end{array}$ & 0.392 & 0.387 & 0.338 & 2.347 & 0.000 \\
\hline
\end{tabular}


Based on the results of the path coefficient, it shows that the effect of the Catur Purusa Arthavalue on product innovation is significant, as indicated by the T statistics value $>1.96$, namely 7.569 or $p$-values are significant $<0.05$. The effect of product innovation on business continuity shows a statistical T value of 3,476 which is greater than 1.96 with p-values significant $<0.05$. The indirect effect between the value of Catur Purusa Artha on business continuity through product innovation can be seen from the bootstrapping output. The results of the indirect effect are presented in Table 4.

Table 4. Indirect Effect

\begin{tabular}{lcccccc}
\hline & & $\begin{array}{c}\text { Original } \\
\text { Sample (0) }\end{array}$ & $\begin{array}{c}\text { Sample } \\
\text { Mean (M) }\end{array}$ & $\begin{array}{c}\text { Standard } \\
\text { Deviation } \\
\text { (STDEV) }\end{array}$ & $\begin{array}{c}\text { T } \\
\text { Statistics }\end{array}$ & P Value \\
\hline $\begin{array}{l}\text { Catur Purusa Artha } \\
\text { Business Continuity }\end{array}$ & Value- & 0.494 & 0.497 & 0.384 & 2.964 & $\mathbf{0 . 0 0 0}$ \\
\hline
\end{tabular}

The magnitude of the coefficient of indirect influence between the value of Catur Purusa Arthaon business continuity through product innovation is 0.494 and significant $<0.05$, greater than the direct effect of 0.392. This means that the better the application of the value of Catur Purusa Artha, it will encourage the right choice of product innovation, which ultimately creates business continuity.

\section{Discussion \\ The Influence of Catur Purusa Artha's Value on Product Innovation}

The test results show that the value of Catur Purusa Artha has a significant effect on product innovation. The values of Catur Purusa Artha as part of the culture applied to BUMDes, apparently affect the behavior of BUMDes employees in creating innovative products offered. This study also found that business management based on the local culture of Catur Purusa Artha by making dharma (truth), as the basis for carrying out all its activities, creates internal conditions in the form of a conducive work climate. BUMDes managers, including all employees who work comfortably based on dharma, have actually come up with creative ideas in product development. The same thing was also expressed by (Matinaro and Liu, 2017) that the prevailing culture in a company provides more innovative and creative thinking. On the other hand, companies with weak culture have more difficulty understanding the elements in innovation so that it becomes a barrier to increasing innovation in their products. Previous research also found that organizational culture can function as a binding chain in the process of equating the perception or direction of members' views on a problem, in responding to challenges and changes that occur in the business (Widodo \& Triwanggono, 2018). Corporate culture is a very important strategic asset because of its role in creating a successful business model (Di Fabio, 2017).

BUMDes in Buleleng regency have realized that cultural values greatly influence the behavior of BUMDes employees. So that the implementation of the value of Catur Purusa Arthawith the concept of dharma as the basis for business management is the right choice. Dharma also teaches that every task that is carried out is not only a responsibility as a BUMDes employee, but how to do it as a form of devotion to God. Business management based on dharma provides awareness to act in the truth, and encourages all BUMDes managers to provide the best service to customers through innovative product offerings. In line with the results of research that a strong organizational culture is a driving force for maximum employee performance which has an impact on company creativity and innovation (Rahmat et al., 2021). A good corporate culture will make it easier to utilize all available resources, thus creating innovation and creating an appropriate innovation strategy (Sunarto, 2020).

\section{The Effect of Product Innovation on Business Continuity}

Innovation plays a key strategic role towards effective sustainable management. Innovation is a strategic component in business continuity as an effort to gain a positive reputation in the minds of customers and appear attractively in intense competition (Alwi \& Handayani, 2018). The test results in this study found that product innovation had a significant effect on business continuity. When BUMDes is able to offer innovative products, which have more value to consumers than competitors, it will produce a competitive advantage and will affect the continuity of its business. MSMEs based on creative industries must have creativity and innovation in their products to be able to survive in today's tight competition. Not only doing creativity and innovation, MSMEs based on creative industries must also have competence in each of their products. By having the competence of these entrepreneurs can facilitate the development of their business (Anggai et al., 2021).

The results of this study also reveal that several BUMDes with good business development offer service products through synergies with local village cottage industry owners and farmers, as well as 
forging outward collaboration with industry. As the BUMDes of wanagiri village is currently doing, BUMDes provides capital assistance to coffee farmers, provides fertilizer needs and the needs to care for coffee plants, the coffee harvest is purchased by BUMDes, branded and marketed in collaboration with outside industries. So that it is not just ordinary credit distribution, this creative idea can revive the village economy and maintain the continuity of the BUMDes business in the midst of the current pandemic. Similar results were also revealed that the company's ability to innovate following market changes can maintain its business continuity (Ani, 2020; Bilan et al., 2020; Mardiyono, 2018). Product innovation has an important role in winning the competition, the times have made consumers able to choose a variety of products, which they will buy (Junedi, 2020). Previous research that innovation cannot be separated from business life because innovation is the spirit or soul in a developing company (Anggraini, Kadir and Nohong, 2020). This is a note for BUMDes in order to survive and be sustainable, it is necessary to innovate quality products.

\section{The Influence of the Value of Catur Purusa Artha on Business Continuity through Product Innovation}

Business continuity can be achieved if there is a synergy of ethical values between the people who create the ideas, and the people who manage them. The ethical values inherent in a person are part of the culture that has been used as a guide for behavior. The results of this study indicate the value of Catur Purusa Artha has a significant effect on business continuity through product innovation. BUMDes that apply the value of Catur purusa artha as a cultural value that is believed to be able to make everyone who is directly involved with BUMDes have the same commitment in building awareness to develop BUMDes. The involvement of the management and all employees through a clear operational plan, then creates more creative ideas through the products offered and finally realizes the continuity of the BUMDes business. This is justified that corporate culture can also be the most important source of excellence in a business model (Lamsihar \& Huseini, 2019). Culture is not related to whether employees like it or not, but in fact, culture is how employees see, feel, and describe their perceptions of the company that lead to creative innovation and business continuity. In the current crisis, focusing on organizational strengths such as cultural values will be the most cost-effective strategy in recovery. The ability of organizational culture to adapt to environmental changes and motivate employees, save organizational resources, will maintain the company in the market and maintain business continuity (Izumi et al., 2019).

This study also found that many BUMDes failed to maintain business continuity, due to internal factors, namely problematic management ranging from lack of human resources and low understanding of business management practices, to triggering fraudulent actions. This is evident from a total of 121 BUMDes opened in Buleleng Regency, which remain active until now only 84 BUMDes. Management of business units based on dharma provides awareness to act in the truth and creates an environment that minimizes abuse of authority, including various other forms of wrongdoing. The concept of dharma also emphasizes to always provide good service to customers. This good service turns out to be one of the determinants of business continuity, in line with the results of research that one of the strengths that creates business continuity is good service to consumers (Soegihartono, 2020). This result is also strengthened through research, the application of the value of catur purusa artha which was tested in cooperatives found that the culture that is firmly held in employees has an impact on improving performance which will affect business continuity (Hendra et al., 2021).

Corporate culture can be used as an organization's mainstay of competitiveness in responding to challenges and changes (Isensee, Teuteberg, and Griese, 2020). Excellence in business is largely determined by the habits, culture developed by a business institution or business entity. A superior company will maintain business continuity. The same thing was also conveyed research on microenterprises where, cultural characteristics maintain core business competencies, create strong and appropriate strategies so that they have excellent innovation outputs in the performance and applicability of SMEs (Miska et al., 2018; Srisathan et al., 2020). In line with the results of this study, research on Indian manufacturing companies, which are one of the fastest growing economies, found that corporate culture affects company resilience in the face of external pressures to maintain business continuity (Dubey et al., 2017). Companies that are oriented to business continuity tend to realize the importance of corporate culture as a driver for employees to increase new product innovation. So that the factor that needs to be a concern for BUMDes is how BUMDes manages a good and conducive work culture in the work activities of all employees, and creates competent and superior innovation products in the market, so that the objectives of BUMDes management can be achieved in accordance with the concept of Catur purusa artha, namely moksa which realized through the continuity of the BUMDes business. 


\section{CONCLUSION}

Based on the formulation of the problem, objectives, theoretical basis, hypotheses and the results of the tests carried out, it can be concluded that: The value of Catur Purusa Artha has a significant effect on product innovation, Product innovation has a significant effect on business continuity, and The value of Catur Purusa Artha affects business continuity through product innovation. This study also found that business management based on the local culture of Catur Purusa Artha by making dharma (truth), as the basis for carrying out all its activities, creates internal conditions in the form of a conducive work climate. BUMDes managers, including all employees who work comfortably based on dharma, have actually come up with creative ideas in product development. Management of business units based on dharma provides awareness to act in the truth and creates an environment that minimizes abuse of authority, including various other forms of wrongdoing. The concept of dharma also emphasizes to always provide good service to customers. BUMDes which has a good culture and is service-oriented, has advantages in product innovation so that it can maintain business continuity in the future and can become a holding company.

\section{REFERENCES}

Alwi, T., \& Handayani, E. (2018). Keunggulan Bersaing Ukm Yang Dipengaruhi Oleh Orientasi Pasar Dan Inovasi Produk. Jurnal Pengembangan Wiraswasta, 20(3), 193. https://doi.org/10.33370/jpw.v20i3.256.

Anggai, A. M., Wolok, T., \& Niode, I. Y. (2021). Membangun Keunggulan Bersaing Produk Melalui Orientasi Pasar Dan Inovasi Produk (Studi Empiris Pada Industri Pengolahan Makanan Jadi Skala Kecil Dan Menengah Di Kotamobagu). Jurnal Ilmiah Manajemen Dan Bisnis, 3(3), 147-157. https://ejurnal.ung.ac.id/index.php/JIMB/article/view/9437.

Anggraini, R., Kadir, A. R., \& Nohong, M. (2020). The Effect of Business Networks, Product Innovation, and Business Competition on the Development of Micro, Small and Medium Enterprises (MSMEs) In Boven Digoel District. Hasanuddin Journal of Business Strategy, 2(4), 53-63. https://doi.org/10.26487/hjbs.v2i4.366.

Ani, L. N. (2020). Pengaruh Inovasi Produk, Kreativitas Produk, Dan Kualitas Produk Terhadap Keunggulan Bersaing (Studi Kasus Pada Kerajinan Tikar Eceng Gondok" Liar". Jurnal Manajemen Dan Bisnis, 2(01), 2076-2086. https://doi.org/10.47080/10.47080/vol1no02/jumanis.

Bilan, Y., Hussain, H. I., Haseeb, M., \& Kot, S. (2020). Sustainability and economic performance: role of organizational learning and innovation. Engineering Economics, 31(1), 93-103. https://doi.org/10.5755/j01.ee.31.1.24045.

Dalimunthe, M. B. (2017). Keunggulan Bersaing Melalui Orientasi Pasar dan Inovasi produk. Jurnal Konsep Bisnis Dan Manajemen, 3(1), 18-31. https://doi.org/10.31289/jkbm.v3i2.357.

Di Fabio, A. (2017). Positive healthy organizations: Promoting well-being, meaningfulness, and sustainability in organizations. Frontiers in Psychology, 8(NOV), 1-6. https://doi.org/10.3389/fpsyg.2017.01938.

Dubey, R., Gunasekaran, A., Childe, S. J., Papadopoulos, T., Hazen, B., Giannakis, M., \& Roubaud, D. (2017). Examining the effect of external pressures and organizational culture on shaping performance measurement systems (PMS) for sustainability benchmarking: Some empirical findings. International Journal of Production Economics, 193, 63-76. https://doi.org/10.1016/j.ijpe.2017.06.029.

Erik Trisnawati, N. L. De, Pasek, G. W., \& Kartika, R. D. (2019). The Value of Catur Purusa Artha and Capital Structure as The Maximization Key of Financial Performance in LPD Buleleng District. International Journal of Social Science and Business, 3(3), 329. https://doi.org/10.23887/ijssb.v3i3.21060.

Ernst \& Young. (2020). COVID-19 business continuity plan: Five ways to reshape. EY, Canada. EY publication. EY Publication. https://www.ey.com/en_ca/transactions/companies-can-reshape-results-andplan-for-covid-19-recovery.

Fabeil, N. F., Pazim, K. H., \& Langgat, J. (2020). The Impact of Covid-19 Pandemic Crisis on MicroEnterprises: Entrepreneurs' Perspective on Business Continuity and Recovery Strategy. Journal of Economics and Business, 3(2). https://doi.org/10.31014/aior.1992.03.02.241.

Ghozali, I., \& Latan, H. (2015). Partial least squares: Konsep, teknik, dan aplikasi menggunakan program smart PLS 3.0 (2nd ed.). Universitas Diponegoro.

Ghozali, I. (2015). Partial Least Square, Konsep Teknik dan Aplikasi menggunakan . SmartPLS 3.0 Untuk Penelitian Empiris. Universitas Diponegoro.

Hendra, I. G., Saputra, E., \& Yasrawan, K. T. (2021). Dampak Moderasi Budaya Catur Purusa Artha pada Pengaruh Self Efficacy dan Locus of Control terhadap Kinerja Koperasi. x(x), 167-178. http://dx.doi.org/10.23887/jiah.v11i1.33439. 
Isensee, C., Teuteberg, F., \& Griese, K.-M. (2020). The relationship between organizational culture, sustainability, and digitalization in SMEs: A systematic review,. Journal of Cleaner Production, 275(December), 122944. https://doi.org/10.1016/j.jclepro.2020.122944.

Izumi, T., Shaw, R., Djalante, R., Ishiwatari, M., \& Komino, T. (2019). Disaster risk reduction and $\begin{array}{lllll}\text { innovations. Progress in } & \text { Sisaster }\end{array}$ https://doi.org/10.1016/j.pdisas.2019.100033.

Junedi, J. (2020). Entrepreneurship Keunggulan Bersaing : Identitas Merek, Inovasi Produk dan Orientasi Pasar Study UMKM Hijab di Kabupaten Bekasi. EKOMABIS: Jurnal Ekonomi Manajemen Bisnis, 1(02), 191-196. https://doi.org/10.37366/ekomabis.v1i02.30.

Kotler, Philip and Keller, K. L. (2016). Marketing Managemen (15th Editi). Pearson Education,Inc.

Lamsihar, A. T., \& Huseini, M. (2019). Transformasi Budaya dan Inovasi Perusahaan BUMN. Inovbiz: Jurnal Inovasi Bisnis, 7, 64-70. https://doi.org/10.35314/inovbiz.v7i1.935.

Lopes, C. M., Scavarda, A., Hofmeister, L. F., Thomé, A. M. T., \& Vaccaro, G. L. R. (2017). An analysis of the interplay between organizational sustainability, knowledge management, and open innovation. Journal of Cleaner Production, 142, 476-488. https://doi.org/10.1016/j.jclepro.2016.10.083.

Mardiyono, A. (2018). The Effect of Market Orientation, Technology Orientation to Increase Marketing Performance on Confection Medium Small Business in Indonesia. Scholars Journal of Economics, Business and Manageent (SJEBM), 562-569. https://doi.org/10.21276/sjebm.2018.5.7.2.

Matinaro, V., \& Liu, Y. (2017). Towards increased innovativeness and sustainability through organizational culture: A case study of a Finnish construction business. Journal of Cleaner Production, 142, 31843193. https://doi.org/10.1016/j.jclepro.2016.10.151.

Miska, C., Szőcs, I., \& Schiffinger, M. (2018). Culture's effects on corporate sustainability practices: A multidomain and multi-level view. Journal of World Business, 53(2), 263-279. https: //doi.org/10.1016/j.jwb.2017.12.001.

Mosteanu, N. R. (2020). Socio-Financial Disruption - Key Tips to Manage and Ensure the Business Continuity. Global Journal of Social Sciences Studies, 6(2), 87-95. https: //doi.org/10.20448/807.6.2.87.95.

Rahmat, M., Akib, H., Rizal, M., Sakawati, H., \& Aslinda, A. (2021). Hubungan Budaya Organisasi Dengan Inovasi Perusahaan Correlation of Organizational Culture with Company Innovation. JENIUS (Jurnal Ilmiah Manajemen Sumber Daya Manusia), 4(2), 145. https://doi.org/10.32493/jjsdm.v4i2.9083.

Rahmawati, E. (2020). Analisis Pengelolaan Badan Usaha Milik Desa (Bum Desa) Di Kabupaten Bandung Barat. Jurnal Ilmiah Ekonomi Bisnis, 25(1), 1-13. https://doi.org/10.35760/eb.2020.v25i1.2386.

Soegihartono, S. (2020). Penelitian Keberlangsungan Usaha Ardani Indonesia Sebagai Umkm Berbasis Industri Kreatif. Solusi, 18(4). https://doi.org/10.26623/slsi.v18i4.2848.

Srisathan, W. A., Ketkaew, C., \& Naruetharadhol, P. (2020). The intervention of organizational sustainability in the effect of organizational culture on open innovation performance: A case of thai and chinese SMEs. Cogent Business and Management, 7(1). https: //doi.org/10.1080/23311975.2020.1717408.

Sunarto, A. (2020). Pengembangan Sumber Daya Manusia dengan Berbasis Inovasi Untuk Menghadapi Revolusi Industri 4.0. Jurnal Ilmiah MEA (Manajemen, Ekonomi, \& Akuntansi), 4(2), 397-407. http://www.journal.stiemb.ac.id/index.php/mea/article/view/504.

Suryaningsih, K. A., \& Kartika, I. N. (2019). Pengaruh Variasi Produk, Pembinaan Usaha,Dan Persaingan Usaha, Terhadap Keberlangsungan Usaha Koperasi. E-Jurnal EP Unud, 8(8), 1789-1823.

Widiarta, P. G. K., Mahardika, I. P. D., Nugraha, N. A. S., Tintara, I. D. G. W., \& Yasa, N. N. K. (2020). Peran Inovasi Produk Memediasi Orientasi Teknologi Terhadap Keunggulan Bersaing. E-Jurnal Ekonomi Dan Bisnis Universitas Udayana, 2, 199. https://doi.org/10.24843/eeb.2020.v09.i02.p05.

Widodo, H. S. T., \& Triwanggono, A. (2018). Karakteristik Budaya Organisasi, Kemampuan Adaptasi, Dan Kinerja Usaha Mikro Kecil Menengah. EXERO : Journal of Research in Business and Economics, 1(1), 90-110. https://doi.org/10.24071/exero.2018.010105. 